Компаративні досліАження слов'янських мов і Аітератур. 2019. Випуск 35

Асноўным спосабам стварэння вобразнасці ў фразеалагізмах са значэннем эмоцый з'яўляецца метафара, таксама сустракаецца метанімія і параўнанне.

Перспектывы даследавання. Праблема фразеалагізмаў са значэннем эмоцый патрабуе далейшага вывучэння. У артыкулі былі разгледжаны толькі намінатыўўныя фразеалагізмы - тыя, што называюць пэўныя эмацыйныя перажыванні чалавека. Разам 3 тым, у слоўніку намі былі зафіксаваны эматыўныя ўстойлівыя выразы, якія выконваюць эматыўную функцыю - з'яўляюцца вербальнымі сродкамі выражэння эмацыйных станаў. Без увагі застаецца праблема функцыянавання фразеалагізмаў са значэннем эмоцый у мастацкім тэксце і жывым маўленні. Перспектыўнай задачай падаецца лексікаграфічнае апісанне такіх адзінак.

\title{
REFERENCES:
}

1. Douhal A. (2008) Srodki vyrazhennya emotsyj u suchasnaj belaruskaj move / A. Douhal, Minsk : Technalohiya,176 p.

2. Lepeshau I. Y. (2008) Slounik frazealahizmau : u 2 t. / I. Y. Lepeshau. - Minsk : Belarus. Entsyklapedyya imya P. Brouki, 2 t.

3. Shakhovskij V. I. (1987) Kategorizatsiya emotsij v leksiko-semanticheskoj sisteme yazyka / V. I. Shakhovskij. - Voronezh : Izdatelstvo Voronezhkogo universiteta, 192 p. 4. Shakhovskij V. I. (2008) Chto takoe lingvistika emotsij? [Elektronnyj resurs] / V. I. Shakhovskij // Mir lingvistiki i kommunikatsii, No 12. - Rezhim dostupa: http://tverlingua.ru.

Заблоцька Ю.

асп., Могильовський університет імені А.А.Кулешова (Республіка Білорусь)

Zablotskaya J. graduate student, Mogilev State A.A. Kuleshov University (Belarus)

\author{
ПАРАНТЭЗА І ПАРЭНТЭЗА: ЗМЕСТ, АБ'ЁМ, \\ НЕАБХОДНАСЦЬ РАЗМЕЖАВАННЯ
}

\section{PARANTESIS AND PARENTESIS: CONTENT, SCOPE, THE NEED TO DIFFERENTIATE}


Стаття присвячена дослідженню термінів парантэза $i$ парэнтэза в мовознавстві, розглядаються межі $i$ підходи до визначення названих понять, запропонованих лінгвістами не тільки різних епох, але $i$ країн. Аналізується схожість $і$ відмінність термінів «вставні» та «вставлені» конструкиії, розглядаються різні класифікаиії таких одиницьь. Обгрунтовується необхідність розмежування понять «парантеза» $i$ «парентеза». Крім того, говориться, щзо паратентичні конструкиії $\epsilon$ засобом формування індивідуального стилю письменника, включаючи авторський стиль В. Короткевича, який яскраво проявляється в художніх творах зазначеного автора.

Ключові слова:: парэнтэза, парантэза, вставні канструкцыі, вставлені канструкиьы, текст, індивідуальний стиль автора.

The article is devoted to the study of such terms as paranthesis and parenthesis in linguistics, which is associated with the interest of many scientists to the existence of these phenomena. The article considers the limits and approaches to the definition of the concepts of "paranthesis" and "parenthesis" proposed by linguists not only from different eras, but also from different countries. The similarity and difference of the terms "introductory" and "inserted" constructions are analyzed, different classifications of such units are considered. It is said that some linguists do not distinguish between the concepts of "introductory" and "inserted" constructions. The necessity of differentiation between the concepts of "parantez" and "parentez" is substantiated. Furthermore, it is stated that pretention design is a means of formation of individual style of the writer, including the style of $V$. Korotkevich, which is clearly manifested in the works of art of the author. The use of parenthetical constructions in literary text is an important element in the system of the author's style, reflects the individual originality of the writer's manner, helps to focus and keep the reader's attention on this or that information, which is mandatory for the understanding of the entire text as a whole.

Key words: parentesis, parantesis, introductory constructions, inserted constructions, text, writer's individual style.

Пастаноўка праблемы. Сінтаксіс сучаснай беларускай мовы валодае багатымі стылістычнымі магчымасцямі. Сінтаксічная экспрэсіўнасць, з'яўляючыся складнікам агульнай выразнасці мастацкага тэксту, становіцца мастацка значным прыёмам уздзеяння на чытача, акцэнтуючы яго ўвагу на 
найбольш важных элементах выказвання [CHupcova A.V. 2016: 157]. М. А. К. Халідэй лічыць, што «сінтаксічныя канструкцыі, актуалізаваныя дзякуючы пэўнаму выбару, <...> могуць служыць сродкам, 3 дапамогай якога пісьменнік перадае сваё бачанне свету, i, магчыма, нават найбольш эфектыўным сродкам» [Hallidej М.A.K. 1980: 138]. Варта адзначыць, што парэнтэтычныя канструкцыі ўяўляюць сабой асаблівы элемент ўскладнення сінтаксічнай структуры простага сказа, які выкарыстоўваецца 3 мэтай «актуалізацыі індывідуальна-аўтарскіх каментарыяў» [Panteleeva E.A. 2005: 6], гэта значыць, яны дапамагаюць абудзіць уяўленне на аснове тэксту (аўтара, апавядальніка) і наладзіць сувязь 3 чытачом. Такім чынам, паратэнтычныя канструкцыі з'яўляюцца сродкам фарміравання індывідуальнага аўтарскага стылю, у тым ліку аўтарскага стылю У. Караткевіча, які ярка праяўляецца ў мастацкіх творах названага пісьменніка.

Сувязь 3 важнымі навуковымі заданнямі. Тэма даследавання непасрэдна звязана 3 агульнакафедральнай тэмай "Мастацкі тэкст у функцыянальным, прагматычным, кагнітыўным і метадычным аспекце”.

Аналіз навуковых крыніц. Праблема парэнтэтычных канструкцый цікавіць вучоных розных школ і напрамкаў. Аналіз літаратурных крыніц паказаў, што парэнтэза як асобная лінгвістычная катэгорыя паўстала i даследуецца параўнальна нядаўна. Варта адзначыць, што пад парэнтэтычнымі адзінкамі звычайна разумеюцца структуры розных узроўняў (слова, словазлучэнне, прэдыкатыўная адзінка, сказ), уключаныя ў сказ, але не звязаныя з асноўным яго зместам сінтаксічнымі сувязямі. Пры вымаўленні дадзеныя канструкцы інтанацыйна выдзяляюцца i характарызуюцца паніжэннем тону i, як правіла, больш хуткім тэмпам маўлення, ix межы падкрэсліваюцца паўзамі, а на пісьме - пунктуацыйна. Парэнтэзы вызначаюцца таксама як метатэкставыя ўкрапленні, што падкрэсліваюць ix камунікацыйцыйную функцыю ў тэксце, паколькі пры дапамозе сінтаксічных уключэнняў такога роду выказванне набывае аб'ёмнасць, у ім актуалізуюцца скрытыя апавядання [Shishkina I.S. 2009: 120].

Мэта артыкула - размежаваць тэрміны “парэнтэза” i “парантэза” i адзначыць іх асаблівасці ў фарміраванні індывідуальнага аўтарскага стылю У. Караткевіча. 
Неабходна ўдакладніць, што хоць парэнтэтычныя канструкцыі інтанацыйна падобныя на даданы сказ, а па сэнсе заўсёды імкнуцца да некаторай паўнавартаснасці, ix самастойнасць адносная, i не можа атаясамлівацца $з$ прэдыкатыўнасцю даданых сказаў. Трэба сказаць, што ў граматыцы выкарыстоўваюцца тэрміны «пабочная» i «ўстаўная» канструкцы як разнавіднасці парэнтэзы. Пры гэтым многія вучоныя размяжоўваюць пабочныя і ўстаўныя канструкцыі.

Што датычыцца паняцця пабочнасці, то ўпершыню яго можна знайсці ў «Практычнай граматыцы рускай мовы» Н. І. Грэча 1827 года: «Пабочны сказ, або парантэза, ёсць зусім старонні сказ, які не мае ніякай граматычнай сувязі $з$ галоўным» [Grech N.I. 1827]. Пры гэтым Н. I. Грэч нічога не гаворыць пра існаванне пабочных слоў. Першапачаткова пабочныя i ўстаўныя канструкцыі аб'ядноўваліся ў паняцце «парантэза». Гэта тлумачыцца наяўнасцю ў дадзеных сінтаксічных адзінак шэрагу агульных уласцівасцяў: семантыкі, надсказавай пазіцыі, пунктуацыйнага афармлення. А ўжо ў сярэдзіне XX ст. мовазнаўцы А. Я. Анікін, I. А. Бабакова, M. А. Карпенка і іншыя, працуючы над размежаваннем аб'ектыўнай і суб'ектыўнай мадальнасці, паступова пачалі аддзяляць пабочныя канструкцы ад устаўных. У канцы XX ст. такія канструкцыі даследаваліся на базе сучасных еўрапейскіх моў. В. В. Вінаградаў апісваў устаўныя сінтагмы, маючы на ўвазе пабочныя і ўстаўныя структуры, і вывучаў іх з пункту гледжання выражэння мадальнасці. Пазней гэтыя канструкцы былі размежаваны.

Наогул, калі мы звернемся да тэорыі вывучэння парэнтэтычных адзінак, то знойдзем другі тэрмін - «парантэза». У падобных выпадках звычайна парэнтэзай называюць толькі ўстаўныя сінтаксічныя адзінкі, а парантэзай пабочныя. «Як і пабочныя, устаўныя канструкцы звычайна сінтаксічна не звязаныя з асноўным сэнсам, але інтанацыйная ізаляцыя іх значна большая, аднак, у адрозненне ад пабочных, устаўныя канструкцыі не выказваюць адносін гаворачага да выказваемай думкі, не ўтрымліваюць ацэнкі паведамлення, указання на яго крыніцы, на сувязь з іншымі сказамі і г.д., а таксама не могуць знаходзіцца ў пачатку сказа. Адрозніваюцца два тыпы ўставак: сінтаксічна не звязаныя з асноўным сказам і сінтаксічна звязаныя 3 
асноўным сказам» [Kocar' EН.В. 1966: 15]. Але пры размежаванні паняццяў «парэнтэза» і «парантэза» трэба памятаць, што гэтае пытанне з'яўляецца спрэчным: «Дакладных крытэрыяў адрознення гэтых канструкцый няма дагэтуль» [AleksandrovaO.V. 1984: 30].

У рускім мовазнаўстве дыферэнцыяцыя ўключаных сказаў заснавана на структурных, інтанацыйных і семантыка-функцыянальных адрозненнях паміж імі. I.І. Шчэбалева і шэраг іншых даследчыкаў (А.Б. Шапіра, I.А. Бабакова) размяжоўваюць устаўныя і пабочныя канструкцыі, звязаныя па сэнсе $з$ асноўным сказам: мадальныя значэнні і эмацыйная адзнака замацоўваюцца за пабочнымі канструкцыямі, а ўстаўныя змяшчаюць дадатковую інфармацыю, удакладненні, тлумачэнні да асноўнага выказвання, але характарызуюцца адсутнасцю мадальнасці. Акрамя таго, асноўным крытэрыем размежавання лічаць выражэнне суб'ектыўнамадальнага значэння пры пабочных і аб'ектыўна-мадальнага - пры ўстаўных канструкцыях [SHishkina I.S. 2009: 121]. У сінтаксічнай школе МДУ імя М. В. Ламаносава на аснове аналізу тэкстаў рознай стылявой прыналежнасці быў зроблены вывад аб тым, што можна трактаваць пабочныя канструкцы як элементы, якія дапаўняюць, каментуюць, а ўстаўныя - як больш самастойныя, менш залежныя ад асноўнай часткі тэксту [Ksenzenko O.A. 1998: 80].

У працах В. В. Аляксандравай у якасці магчымых крытэрыяў размежавання названых канструкцый прыводзяцца наступныя:

1) прасадычны (3 пункту гледжання роўнага або няроўнага тона апавядання пабочныя канструкцыі, у адрозненне ад ўстаўных, не вылучаюцца на фоне асноўнага выказвання);

2) графічны (пунктуацыйна пабочныя канструкцы ў асноўным вылучаюцца коскамі, у той час як устаўныя - 3 дапамогай дужак і працяжніка). Трэба адзначыць, што прадстаўнік структурнага напрамку С. Грынбаум таксама да парэнтэтычных канструкцый адносіць толькі тыя, што заключаюцца ў дужкі і ўключаць у сябе тлумачэнне [SHishkina I.S. 2009: 121].

Услед за Н.С. Валгінай, В.В. Бабайцавай, А.С. Скоблікавай, разглядаючы пытанні размежавання ўстаўных і пабочных канструкцый, варта заўважыць: 
1) устаўныя і пабочныя канструкцыі маюць некаторае падабенства, аднак нельга іх атаясамліваць, паколькі гэтыя паняцці самастойныя, аўтаномныя i адрозніваюцца не толькі сваёй мэтанакіраванасцю, але і структурнымі, семантычнымі, пазіцыйнымі, інтанацыйнымі характарыстыкамі;

2) устаўныя канструкцы адрозніваюцца ад пабочных не толькі функцыянальна, лексіка-граматычнымі асаблівасцямі ў сінтаксічным афармленні (парадак слоў, характар унутранай структуры і таму падобнае), сэнсавым значэннем, але і з прычыны рознага характару інтэнцый, якія імкнецца рэалізаваць той, хто гаворыць;

3) нягледзячы на самастойны інтанацыйны контур і ўласны фразавы акцэнт, устаўныя канструкцыі можна ахарактарызаваць як інтанацыйна самастойныя стварэнні ў адрозненне ад пабочных;

4) устаўныя канструкцы могуць мець у сваім складзе пабочныя, у той час як адваротная з'ява немагчыма;

5) 3 пункту гледжання камунікацыйна-прагматычнай лінгвістыкі пабочны элемент вызначаецца як кампанент выказвання, што фарміруе мадальны план і рэалізуе пэўныя камунікацыйна-прагматычныя ўстаноўкі таго, хто гаворыць; устаўны ж элемент, $з$ аднаго боку, вызначаецца як асаблівая сінтаксічная з'ява, якая выходзіць за межы і ўскладненага, i складанага сказа, з другога боку - як з'ява, якая структурна ўскладняе сказ, у які ўваходзіць, а на ўзроўні выказвання стварае «двотэкст» і выражае метакамунікацыйны змест [Serdyuk N.YU. 2012: 93].

Для мастацкіх твораў У. Караткевіча характэрна выкарыстанне пабочных канструкцый унутры ўстаўных:

- Но, - зусім нечакана сказаў Крэбс (а ехай жа, здаецца, далёка). Англічан можна. Нельга глюпых $і$ зльх жартаўнікой, якія лічачь англічан дур-ны-мі. Ад іх у ваўка бр-рум у жываце («Каласы пад сярпом тваім»).

- I тым, праўдзівей сваёй смерию (можа, не выпадковай), адсек ямчэ адну пуияводную ніџь. $A$ «дружкі» загінулі таксама у зменлівасиях падзей вайны. І ияпер нават прыблізна, нават няпэуна, па чутках ведалі пра сховы архіва, старога скарбу $і$ таго, што нарабавала ведамства Розенберга, толькі тры чалавекі. Два бандзюкі - $і$ нашым і вашым - $i$ вы, апошні ліст на дрэве, квячіна ў крапіве («Чорны замак Альшанскі»). 
Але $\check{y}$ той час я $\check{y}$ гльбіні душы (хоць і лічьуцся «чырвоным») быу перакананы, што не толькі з шыбеніи растуць на зямлі лясы (што, вядома, было правільным нават у часыЯзафата Кунцэвіча і беларускай доказнай інквізіцыі) $і$ не толькі стогн адчуваециа ў нашых песнях («Дзікае паляванне караля Стаха»).

Украінская даследчыца 3. П. Алейнік, аналізуючы катэгорыю пабочнасці і катэгорыю ўстаўленасці, адзначае:

1) абедзве катэгорыі, нягледзячы на набліжанасць у функцыянальным плане, не спалучаюцца ні па форме, ні па функцыі, ні па значэнні;

2) устаўныя канструкцыі, выконваючы дыферэнцыяльную функцыю, збліжаны 3 катэгорыяй суб'ектыўнай мадальнасці, аднак не з'яўляюцца сродкамі яе выказвання;

3) выразы, якія змяшчаюць пабочныя і ўстаўныя кампаненты, уяўляюць з сябе шматузроўневую інфармацыйна-прагматычную структуру;

4) пабочныя і ўстаўныя кампаненты рэалізаваны на аснове сінтаксічных сувязяў, што пярэчыць традыцыйным поглядам пра іх сінтаксічную нязвязнасць, ізаляванасць;

5) устаўныя кампаненты маюць узуальны характар;

6) устаўныя кампаненты з'яўляюцца вынікам суб'ектыўнага члянення / дадаткам інфармацыйнага поля выказвання;

7) катэгорыя ўстаўленасці выконвае стылістычную і стылеўтваральную функцыю;

8) катэгорыі пабочнасці / устаўкі прадстаўляюць універсальную катэгорыю суб'ектыўнасці ў мове;

9) катэгорыі пабочнасці / устаўкі выступаюць сродкам структуравання тэксту (дыскурсу) [Olejnik Z.P. 2002: 57-58].

Што датычыцца беларускага мовазнаўства, то тут даследчыкі не звяртаюцца да пытання размежавання паняццяў «парантэза» і «парэнтэза». Аднак, напрыклад, у працах В. У. Русак выкарыстоўваецца тэрмін «парантэза». Даследчык лічыць, што парантэтычныя ўстаўкі сінтаксічна адпавядаюць устаўным канструкцыям рознай структуры: устаўным словам, устаўным словазлучэнням, устаўным сказам [Rusak V.U. 2016: 201].

Неабходна ўказаць, што ў нямецкай сінтаксічнай традыцыі пабочныя $\mathrm{i}$ ўстаўныя элементы не размяжоўваюцца. Што датычыцца 
англаамерыканскай лінгвістыкі (Р. Пэнс, Х. Глісан, А. Хіл, , К. Фолкнер, Г. Суіт, С. Грынбаум), то пытанне аб размежаванні пабочных і ўстаўных канструкцый разглядаецца па-рознаму. Напрыклад, у К. Фолкнера крытэрыем адрознення 3'яўляецца наяўнасць або адсутнасць ва ўстаўных канструкцыях граматычнай сувязі са сказам. Г. Суіт падзяляе парэнтэзу на «ўласна парэнтэзу», якая знаходзіцца ў інтэрпазіцыі, і «далучальную парэнтэзу», прыпісваючы пазіцыйнаму размяшчэнню вызначальную ролю [SHishkina I.S. 2009: 121]. Пры гэтым неабходна памятаць, што пры інтэрпазіцыйным увядзенні ў сказ парэнтэза можа размяжоўваць элементы прэдыкатыўнага ядра сказа. На думку Л. Х. Лустрэ, такое размяшчэнне парушае паступальнае развіццё апавядання і затрымлівае рэалізацыю прэдыкатыўных сувязі: частка сказа, прадстаўленая групай дейніка, спараджае эфект чакання структурнага і сэнсавага завяршэння. Кампазіцыя такой пабудовы - разарваная будова прэдыкатыўнага ядра і пунктуацыйная вылучанасць парэнтэтычнай групы - прыкоўвае да сябе ўвагу, забяспечвае актывізацыю ўспрымання тэксту чытачом [Mashanova K.V. 2015: 90].

Шэраг іншых лінгвістаў (А. I. Анікін, А. П. Скавароднікаў, М. Д. Коваль, Ю. М. Скрабнёў) адносяць да парэнтэз толькі ўстаўныя канструкцыі, выразна супрацьпастаўляючы іх пабочным. А. І. Анікін адзначае «несамастойнасць i тыпізаванасць значэнняў пабочных канструкцый», якія рэалізуюць асноўную функцыю перадачы значэння суб'ектыўнай мадальнасці, інакш кажучы ўстаноўленых субяседнікам адносін зместу выказвання да рэчаіснасці [Anikin A.I. 1975: 21-22]. Непасрэдна стылістычнай функцы яны не маюць. У той жа час устаўныя сказы характарызуюцца значнай самастойнасцю i разнастайнасцю семантыкі, а таксама рэалізуюць шэраг стылістычных функцый, найважнейшай з якіх з'яўляецца стварэнне двух паралельных маўленчых планаў [Kuznec M.D., Skrebnev YU. M. 1960: 79-80].

Цікава, што большасць вучоных схільна думаць, што межы паміж пабочнымі словамі, спалучэннямі слоў і сказамі расплывістыя. Дадзенае меркаванне падзяляе Н. С. Валгіна, якая лічыць, што многія пабочныя сказы збліжаюцца 3 пабочнымі словамі і словазлучэннямі. Гэта выяўляецца ў тым, што, выражаючы адны і тыя ж значэнні, яны адрозніваюцца толькі 
аб'ёмам і ступенню распаўсюджанасці (напрыклад: вядома - мне вядома, усяму гораду вядома; памятаю - колькі памятаю; здавалася - мне здавалася; уявіще -можаце сабе ўявіџь $i$ г. д.). Такое супастаўленне пабочных слоў, спалучэнняў слоў і сказаў сведчыць аб адсутнасці рэзкіх межаў паміж імі. Асабліва паказальныя ў гэтым плане аманімічныя сінтаксічныя канструкцыі, якія адрозніваюцца выключна функцыянальна. Параўнаем: Вядома, што ён добры хлопец (вядома - галоўная частка складаназалежнага сказа). Вядома, ён добры хлопеи (вядома - пабочны сказ). Ён, вядома, добры хлопец (вядома - пабочнае слова) [Valgina N.S. 2003: 250-251]. 3 гэтым меркаваннем згодны і даследчык Ю. К. Пузікаў: «Парэнтэтычныя сказы выклікаюць асаблівыя складанасці ў навучэнцаў» [Puzikov YU.K. 1980: 22].

Неабходна адзначыць, што «пабочныя словы» і «пабочныя сказы» прынята адносіць да розных структурных адзінк, хоць яны маюць аднолькавыя ўласцівасці і функцыі. У прыватнасці, Э. Б. Коцар, апісваючы парэнтэтычныя канструкцыі, адзначаў: «найчасцей сустракаюцца наступныя тыпы структур пабочных сказаў:

1) двухсастаўныя сказы тыпу я бачу, я памятаю, я дапускаю, mbl ведаеш, мы перакананыя і г. д.

2) няпэуна-асабовыя сказы тыпу кажуць, так думалі, яму сказалі і г. д.

3) безасабовыя сказы тыпу думалася ёй, яму здалося, мне здавалася, нельга не пагадзіциа, пара прызнаць і . ..» [Kocar' ЕН.В. 1966: 13-14].

Так, у мастацкіх творах У. Караткевіча мы знойдзем такія канструкцыі:

- Не магу. Як нібы зрабіў сваю справу. А тут яшчэ кожную нядзелю пеўні, каровы, коні - ну кліча нешта, і ўсё. Каб яшчэ не раён гэты кляты. А тут бачу - парсючок, пярэсиенькі. Я ж, здавалася б, гараджанін, я ж араць не уммею. А тут - ну хоць бы рыдлёўку ў рукі... Бэз зазелянеў, зямля пахне, тлустая такая. На агрэсие зялёнае воблака... Паеду да Maрыны. Там сад, будзем двох корпациа. А ты - толькі ияпер, глядзі, жаніся («Чорны замак Альшанскі»).

- А Райбіч, кажуць, сапраўды чараўнік. Бо ні з чым не змірыўся, як унію знішчылі, $i$, кажуць, у першую ж ноч прадаў д'яблу душу, абы толькі не паіхняму выйшла... («Каласы пад сярпом тваім»). 
Зноу чемра агарнула куты заль, у якой яшчэ, здавалася, жылі гукі музыкі і смех («Дзікае паляванне караля Стаха»).

Абапіраючыся на акадэмічныя вызначэнне мадальнасці як адносіны паведамлення да рэчаіснасці, да рэальнага ажыццяўлення, М. Я. Баскова прапануе падзяляць пабочныя словы на 2 вялікія групы: пабочныя словы 3 мадальным значэннем і пабочныя словы без мадальнага значэння [Boskova M.E. 1956: 3].

Існуюць больш дробныя класіфікацыі парэнтэтычных канструкцый, у аснову якіх пакладзены розныя класіфікацыйныя прыкметы: форма, значэнне, функцыя, магчымасць займаць пэўную пазіцыю ў сказе і г. д.

Найбольш шырока i паслядоўна распрацавана класіфікацыя па структуры, у аснову якой пакладзена марфалагічнае афармленне пабочных слоў. Да таго ж, існуе некалькі класіфікацый парэнтэтычных канструкцый у залежнасці ад таго, якімі элементамі гэтыя канструкцы могуць быць прадстаўлены ў мове.

Звычайна ў ролі пабочных слоў выступаюць прыслоўі, дзеясловы i іншыя часціны мовы, асноўным прызначэннем якіх з'яўляецца выражэнне адносін таго, хто гаворыць, да таго, пра што ён паведамляе. Але большая частка парэнтэз уяўляе 3 сябе спецыфічнае ўжыванне тых ці іншых знамянальных слоў ці іх спалучэнняў. Яны могуць быць іменнымі або дзеяслоўнымі: «У функцыі пабочных слоў ўжываюцца разныя часткі маўлення. У выніку ўжывання слоў у якасці пабочных сярод іх вылучаецца асаблівы разрад слоў, якія адрываюцца ад сваёй парадыгмы, страчваюць здольнасць змяняцца, для якіх функцыянаванне ў якасці пабочных становіцца асноўнай (а нярэдка і адзінай) функцыяй» [Grech N.I. 1827: 5].

Пры вывучэнні парэнтэтычных канструкцый варта звярнуць увагу, што многія словы вылучаюцца як графічна, так і інтанацыйна як парэнтэзы, такімі на самай справе не з'яўляючыся. Адсюль узнікае шэраг памылак у вобласці пунктуацы, стылістыкі і культуры мовы. Пры гэтым да гэтага часу няма адзінага спісу, у якім пералічваліся б усе магчымыя псеўдапарэнтэзы [Antonova V.V. 2015: 19].

Высновы. Стылістычныя асаблівасці пабочных $\mathrm{i}$ ўстаўных канструкцый некалькі адметныя, аднак яны аб'ядноўваюцца тым, што 
могуць змяшчаць імпліцытную інфармацыю або быць сродкам імпліцытнага насычэння мастацкага твора, уплываць на фарміраванне індывідуальнага аўтарскага стылю. Шырокае выкарыстанне парэнтэзы ў мове пісьменніка сведчыць пра адпаведную стылістычную арыентацыю дадзенага аўтара. Наяўнасць парэнтэтычных канструкцый у мастацкіх творах - гэта найважнейшы элемент у сістэме аўтарскай паэтыкі, які адлюстроўвае індывідуальную своеасаблівасць аўтарскай манеры, дапамагае завастраць і ўтрымліваць увагу чытача, набліжае тэкст да гутарковай мовы.

Надалей намі будуць разглядацца асаблівасці як парэнтэтычных, так і парантэтычных канструкцый. Тым не менш, мы не будзем настойваць на неабходнасці расшчаплення тэрміна і аб'яднаем два тэарэтычна розных паняцці уу адно «парэнтэза». Дадзеная неабходнасць тлумачыцца асноўнай мэтай дальнейшай працы - апісанні парэнтэтычных канструкцый у функцыянальна-стылістычны аспекце, а не доказу неабходнасці расшчаплення тэрмінаў для дзвюх падобных з’яў у мове.

\section{REFERENCES:}

1. Aleksandrova, O.V. (1984). Problemy expressivnogo sintaksisa, 211 s. (Moskva).

2. Anikin, A.I. (1975). Sootnoshenie vvodnyh i vstavnyh konstrukcij v sovremennom russkom yazyke, 19-33 (Moskva).

3. Antonova, V.V. (2015). Parentetichsekie konstrukcii sovremennogo russkogo yazyka v lingvokul'turologicheskom aspekte, 155 1. (Moskva).

4. Boskova, M.E. (1956). Soyuznye funkcii vvodnyh slov i vvodnyh sochetanij slov v sovremennom russkom yazyke, $20 \mathrm{~s}$. (Riga).

5. Valgina, N.S. (2003). Sovremennyj russkij yazyk, 416 s. (Moskva).

6. Grech, N.I. (1827). Prakticheskaya russkaya grammatika, 588 s. (Sankt-Peterburg).

7. Ickovich, V.K. (1954). K istorii vvodnyh slov, slovosochetanij i predlozhenij v russkom yazyke, 16 s. (l'vov).

8. Kocar', EH.B. (1966).Vvodnye slova i slovosochetaniya, vvodnye predlozheniya, vstavnye konstrukcii, $16 \mathrm{~s}$. (Moskva).

9. Ksenzenko, O.A. (1998). Kak sozdayotsya reklamnyj tekst, 168 s. (Moskva).

10. Kuznec, M.D., Skrebnev, YU. M. (1960). Stilistika anglijskogo yazyka, 168 s. (Leningrad). 
11. Mashanova, K.V. (2015). Funkcii kommentiruyushchih konstrukcij pri realizacii avtorskogo zamysla $\mathrm{v}$ angloyazychnyh tekstah biznes-tematiki. Evrazijskij Soyuz Uchenyh (ESU). Filologicheskie nauki, 4 (13), 89-91 (Moskva).

12. Olejnik, Z.P. (2002). Vvodnye i vstavochnye komponenty v strukture vyskazyvaniya i teksta, 340 1. (Doneck).

13. Panteleeva, E.A. (2005). Kommunikativno-pragmaticheskie svojstva vvodnyh i vstavnyh ehlementov v sovremennom russkom yazyke, $20 \mathrm{~s}$. (Volgograd).

14. Puzikov, YU.K. (1980). Rabota po razvitiyu rechi uchashchihsya pri izuchenii vvodnyh slov i vvodnyh predlozhenij, $39 \mathrm{~s}$. (Leningrad).

15. Rusak, V.U. (2016). Figury razmyashchehnnya i perastanoy̆ki yak srodki rehalizacyi ehmatyy̆nasci mastackaga may̆lennya. Trudy BGTU, 5, 198-203 (Minsk).

16. Serdyuk, N.YU. (2012). Parentetichni konstrukciï v suchasnomu anglijs'komu hudozhn'omu tvori. Naukovi zapiski. Seriya «Filologichna», 30, $92-95$ (Kiev).

17. Hallidej, M.A.K. (1980). Lingvisticheskaya funkciya i literaturnyj stil. Novoe v zarubezhnoj lingvistike, 9, 116-147 (Moskva).

18. CHupcova, A.V. (2016). Funkcii parentezy v originale i perevode. Filologicheskie nauki. Voprosy teorii i praktiki, 5 (59), 157-161 (Tambov).

19. SHishkina, I.S. (2009). Paranteza v anglijskom i nemeckom yazykah: semantikosintaksicheskie osobennosti i graficheskoe oformlenie. Vestnik Vyatskogo gosudarstvennogo gumanitarnogo universiteta, 2-2, 120-125 (Kirov).

Казімірська T.

ст. викл., Могильовський університет імені А.А.Кулешова (Республіка Білорусь)

Kazimirsky T.

senior lecturer, Mogilev state University named A. A. Kuleshov (Republic of Belarus)

\section{СТЫЛІСТЫЧНАЯ РОЛЯ ФРАЗЕАЛАГІЗМАЎ У ТВОРАХ А. МАКАЁНКА}

\section{STYLISTIC ROLE OF PHRASEOLOGY IN THE WORKS OF A. MAKAENKA}

У статті йдеться про стилістичне використання фразеологізмів у творах А. Макаєнка. Увага звертається як на нормативне, так $i$ на індивідуально- 